(RESEARCH ARTICLE)

\title{
Gunshot injuries in Owerri, a 10 years (2001-2010) postmortem study.
}

\author{
Nnadi IKechukwu Godfrey * and Odowueze Egejuru Raphael \\ Department of Histopathology, Federal Medical Centre Owerri, Imo State, Nigeria.
}

Publication history: Received on 14 January 2020; revised on 21 May 2020; accepted on 24 May 2020

Article DOI: https://doi.org/10.30574/wjarr.2020.7.2.0011

\begin{abstract}
This study is to establish the demographic parameters, typical entry and exit wound sites, immediate causes of death and annual incidence of gunshot injuries in Owerri. The records of gunshot victims in the case notes, Post-mortem registers, departmental and medical records databases of FMC Owerri were used as the sources of data for this study from January 2001 to December 2010. One hundred and one cases of gunshot injuries (GSI) that resulted in death met the inclusion criteria of this study. Ninety-six per cent of the victims were males; mean age was $52.2 \pm 21.3$ years and age range of 19-71 years. The most affected age groups were those in the 21-30 years age groups followed by 31-40 years. The most frequent site of entry wound was thorax (36.7\%), followed by head and neck region (22.8\%), abdomen (19.8\%) and lower limbs (13.9\%). A total of 56.4\% (57cases) had established sites of exit wounds while in $33.7 \%$ (34 cases) the exit wounds were not defined. The incidence of GSI was highest in 2003 (17.82\%), followed by 2008 (14.85\%) and 2007 (13.46\%). The immediate causes of death were a haemorrhagic shock in 84 cases (83.2\%), head injuries with skull fractures 10cases (9.9\%) and septicaemia in 7 cases (6.9\%). Effective legislation and gun control policy would prevent the unnecessary death of our young men through violence, gangsterism and substance abuse.
\end{abstract}

Keywords: Gunshot, Injuries, Postmortem, Owerri

\section{Introduction}

Deaths due to gunshot injuries continue to increase the world over with variation in its incidence in different parts of the world [1]. Obalum et al. [2] reported that the rising incidence rate of gunshot injuries (GSI) remains one of the leading causes of death, extended hospitalization and economic losses worldwide. The severity of gunshot injuries depends on the effects of the mechanical interaction between the bullet and tissues with resultant cavities produced by the pellets [3]. In high-income countries like the USA, a significant number of gunshot wounds relates to suicide attempts unlike in developing countries where the spates of communal and ethnic clashes, political violence and armed robberies are the predominant causes of GSI [4, 5, 6]. In Maiduguri, Abbas et al. [7] reported that gunshot injuries were rare in Nigeria until the civil war of 1967-1970, with marked involvement of males. Gunshot violence has, besides its medical importance, also an enormous economic impact as the third most costly aetiology of injury and the fourth most expensive form of hospitalization [8].

The objective of this study is to establish the demographic parameters, typical entry and exit wound sites, immediate causes of death and annual incidence of gunshot injuries in Owerri, the capital city of Imo State, Nigeria.

\section{Material and methods}

The records of gunshot victims in the patient's case notes, postmortem registers, and databases of the Departments of Pathology and Medical records of FMC Owerri were used as the sources of data for this study from January 2001 to December 2010. The complete post-mortem examination was done by Consultant Pathologists in the Department of Pathology, using laid down protocols. The postmortem findings were analyzed for age, sex and cause of death as well as

\footnotetext{
* Corresponding author: Nnadi IKechukwu Godfrey; Phone number +2348038147448; email: godheniknnd@yahoo.com
} 
some vital anatomic parameters to establish the immediate causes of death, the entry and exit wound sites. These data were analyzed using SPSS version 16.

\section{Results}

Of 486 autopsies performed in the period under review, 101 cases were due to gunshot injuries which constituted $20.8 \%$ of all the postmortem examinations conducted in FMC Owerri. Ninety-six per cent of the victims were males; mean age was $52.2 \pm 21.3$ years and the age range was $19-71$ years. The most affected age groups were those in the 2130 age groups followed by 31-40 years. There was no case of GSI in the pediatric age group (1-18 years); however, there were 5 cases (4.95\%) involving victims that were 19 and 20 years old. Table 1 shows the distribution of the gunshot victims among these age groups. The most frequent site of entry wound was the thorax (chest), followed by the head/neck and abdomen. Table 2 and 3 show the distribution of entry and exit wounds, respectively, in all the regions of the body. The highest cases of GSI occurred in 2003, followed by 2009. Table 4 illustrates the annual incidence of GSI.

Table 1 The distribution of the gunshot victims among the age groups.

\begin{tabular}{llll}
\hline S/n & Age group & Frequency & $\mathbf{\%}$ \\
\hline 1 & $1-10$ & 0 & 0.00 \\
2 & $11-20$ & 5 & 4.95 \\
3 & $21-30$ & 49 & 48.51 \\
4 & $31-40$ & 19 & 18.81 \\
5 & $41-50$ & 15 & 14.85 \\
6 & $51-60$ & 8 & 7.92 \\
7 & $61-70$ & 4 & 3.96 \\
8 & $71-80$ & 1 & 0.01 \\
Total & & 101 & 100 \\
\hline
\end{tabular}

Table 2 The distribution of all the entry wounds in different parts of the body

\begin{tabular}{llll}
\hline s/n & Region & Frequency & $\mathbf{\%}$ \\
\hline 1 & Thorax & 37 & 36.7 \\
2 & Head and neck & 23 & 22.8 \\
3 & Abdomen & 20 & 19.8 \\
4 & Lower limb & 14 & 13.9 \\
5 & Pelvis & 3 & 2.97 \\
6 & Upper limb & 1 & 0.01 \\
7 & Undetermined & 3 & 2.97 \\
Total & & 101 & 100 \\
\hline
\end{tabular}

Table 3 The distribution of all the exit wounds in different parts of the body

\begin{tabular}{llll}
\hline s/n & Region & Frequency & $\mathbf{\%}$ \\
\hline 1 & Thorax & 19 & 18.81 \\
2 & Head/neck & 17 & 16.83 \\
3 & Abdomen & 11 & 10.89 \\
4 & Lower limb & 6 & 5.94 \\
5 & Pelvis & 3 & 2.97 \\
6 & Upper limb & 1 & 0.99 \\
7 & Retained bullet & 10 & 9.90 \\
8 & undetermined & 34 & 33.66 \\
Total & & 101 & $100 \%$ \\
\hline
\end{tabular}


Table 4 Shows the annual incidence of gunshot injuries in Owerri.

\begin{tabular}{llll}
\hline s/n & Year & Frequency & $\mathbf{\%}$ \\
\hline 1 & 2001 & 4 & 3.96 \\
2 & 2002 & 6 & 5.94 \\
3 & 2003 & 18 & 17.82 \\
4 & 2004 & 8 & 7.92 \\
5 & 2005 & 4 & 3.96 \\
6 & 2006 & 8 & 7.92 \\
7 & 2007 & 14 & 13.46 \\
8 & 2008 & 12 & 11.88 \\
9 & 2009 & 15 & 14.85 \\
10 & 2010 & 12 & 11.88 \\
Total & & 101 & 100 \\
\hline
\end{tabular}

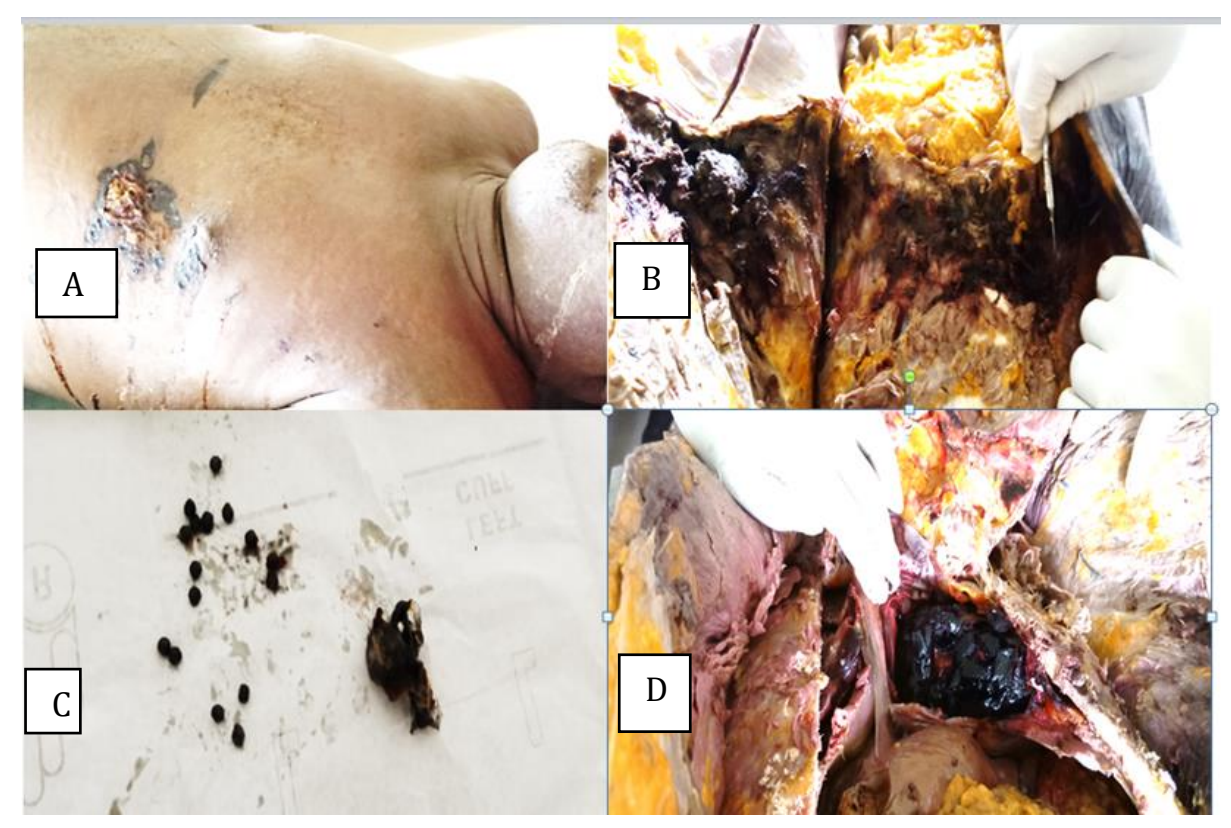

Figure 1 A- Photomicrograph showing entry wound in the left thoracic region just below the left nipple. B- Shows the charred bullet tract across the anterior chest wall of the victim. C- Shows sixteen metal pellets and plastic canister. DShows massive haemothorax with cardiac tamponade.

\section{Discussion}

Gunshot wounds are becoming a common public health problem worldwide with a recent increase in developing countries due to poverty, unemployment, political instability and unequal distribution of wealth [9, 10]. In this study, ninety-six per cent of the victims were males, and the mean age was $52.2 \pm 21.3$ years with age range of $19-71$ years. The most affected age groups were those in the 21-30 years age group, followed by 31-40 years age groups and $70 \%$ of the victims were aged 21-50 years. These observations agreed with previous studies $[11,12,13,14,15,16,17,18]$. However, several reports demonstrated that gender disparity was less marked in Abia, Tanzania and Texas [19, 20, 21, $22,23]$. In this study, there were five cases of gunshot-related death in the victims aged 10-20 years, constituting about $4.95 \%$ of all cases. However, in Connecticut USA, Zavoski et al. [24] reported that more than $80 \%$ of deaths from gunshot wounds occurred among 15 to 19 -year-old males. A similar report from Pakistan demonstrated that $53.4 \%$ of children involved in gunshot-related suicide were aged 16-20 years [22]. 
The predictors of the severity of gunshot injuries were the site of the entry wound, the velocity of the bullet and factors associated with higher energy transfer such as bullet fragmentation and bone fractures [25]. In this study, the most frequent site of entry wound was thorax (36.7\%), followed by head and neck region (22.8\%), abdomen (19.8\%) and lower limbs (13.9\%). These observations agreed with other studies [13, 16, 22, 26]. However, reports from different parts of Nigeria and Africa showed that the extremities were the most frequent site of entry wounds in gunshot victims $[2,7,9,11,14,18,23,21]$. This was because most gunshot injuries in these places were due to armed robbery in which the criminals were not in dire need to take the life of their victims as compared to our areas where GSI were related to kidnapping, homicide, civil conflicts and brutality from armed security personnel [2, 6, 7, 12, 21, 29]. Although the site of entry wound could suggest the intention of the assailant, the study of bullet tracts were usually instrumental in differentiating between suicide and homicide [30].

The exit wounds followed the pattern of the entry wounds. A total of $56.4 \%$ ( 57 cases) had identified sites of exit wounds while in 33.7\% (34 cases) the exit wounds were not established. Furthermore, 9.9\% (10cases) of the victims had bullet canisters and pellets lodged in their bodies. In Durban South Africa, Inchien et al. [13] reported that 53\% of patients with GSI had established exit wounds while $47 \%$ had a bullet lodged in their bodies. The large proportion of undetermined cases of exit wound could be reduced if post-mortem roentgenography were used to detect metal pellets lodged in tissues.

The incidence of GSI was highest in 2003 (17.82\%), followed by 2008 (14.85\%) and 2007 (13.46\%). Most of these years corresponded to general elections, times of exacerbated kidnapping, armed robbery and conflicts among local criminal gangs $[7,14,16,31]$.

Injuries following GSI were usually fatal. In this study, the majority of the entry wounds were located in the thorax, which contains vital viscera. The immediate causes of death were haemorrhagic shock in 84 cases (83.2\%), head injuries with skull fractures 10 cases (9.9\%) and septicaemia 7cases (6.9\%). Similar observations were made in Irrua, Texas and Serbia $[12,19,29]$. In Maiduguri, North-east Nigeria wound infections were the leading cause of death. Ojo and Aliyu et al. $[23,32]$ reported that $3.4 \%$ and $2.7 \%$ of victims died of septicemia, respectively.

\section{Conclusion}

The proliferation of illegal arms and ammunitions in our society has grave consequences on the behaviour of our youths; this has caused loss of lives of males in their prime age of productive lives. There is a dire need for effective control legislation and enforcement to eradicate illegal arms possession, criminal gang formation and drug abuse among our youths.

\section{Compliance with ethical standards}

\section{Acknowledgments}

We sincerely thank the staff of the Histopathology and Medical Records Departments of Federal Medical Centre, Owerri for the roles they played in the provision of information we needed for this study and helping out in all the necessary verifications of the data during the period this research was conducted.

\section{Disclosure of conflict of interest}

The authors declare no conflict of interest.

\section{Ethical approval}

The research ethics approval was obtained from Health research ethics committee of Federal Medical Centre Owerri. The approval number is FWC/OW/HREC/132

\section{References}

[1] Rawson B. Aiming for Prevention: Medical and Public Health approaches to small arms, gun violence and injury. Croatian Medical Journal. 2002; 4, 379-85.

[2] Obalum DC, Giwa SO and Ogo CN. Pattern of extremity gunshot injuries seen in Lagos University Teaching Hospital, Lagos, Nigeria. Nigerian Quarterly Journal of Hospital Medicine. 2007; 17(4), 140-3. 
[3] Kohhneier RE, Mcmahan CA and Dimaio VJM. (2001). Suicide by gunshot. American journal of Forensic Medicine and Pathology. 2001; 22:337-340

[4] Krug EG, Powell KE and Dahlberg LL. Firearm-related deaths in the United States and 35 other high- and uppermiddle-income countries. International Journal of Epidemiology. 1998; 27: 214-221.

[5] Archampong EQ. Wounds and wound healing. In: Badoe EA, Achampong EQ, da ocha-Afodu JT (EdS). Principles and Practice of Surgery in the tropics, including Pathology in the tropics, 3rd Edition. Ghana Publishing Corporation, p53-64.

[6] Afuwape 0 and Alonge T. An Audit of gunshot injuries seen in the accident and emergency department of a Nigerian Tertiary Hospital. West African Journal of Medicine. 2006; 25:295-297.

[7] Abbas AD, Bakari AA and Abba AM. Epidemiology of armed robbery-related gunshot injuries in Maiduguri, Nigeria. Nigerian Journal of Clinical Practice. 2012; 15: 19-22.

[8] Volgas DA, Stannard JP and Alonso JE. Current orthopaedic treatment of ballistic injuries. Injury. 2005; 36: 380386

[9] Mohammed AZ, Edino ST, Ochicha O and Umar AB. Epidemiology of gunshot injuries in Kano, Nigeria. Nigerian Journal of Surgical Research. 2005; 7(3):296-299.

[10] Solagbem BA. Epidemiology and outcome of gunshot injuries in a civilian population in West Africa. European Journal of Trauma. 2003; 29:92-6.

[11] Aigoro N and Abass G. Epidemiology of Gunshot Injuries In Abeokuta, Southwest Nigeria. Internet Journal of Orthopaedic Surgery. 2013; 20(1):1-4.

[12] Onuminya JE and Ohwowhiagbese E. . Pattern of civilian gunshot injuries in Irrua, Nigeria. South African Journal of Surgery. $2005 ; 43(4): 170-2$.

[13] Inchien Chamisa. Civilian abdominal gunshot wounds in Durban South Africa. Annals of the Royal College of Surgery of England. 2008;90:581-586

[14] Chalya PL, Mchembe M, Mabula JB, Kanumba ES and Gilyoma JM. Gunshot injuries: A Tanzanian experience in a Teaching hospital in the Lake Zone. East and Central African Journal of Surgery.2011; 16(1): 19-25.

[15] Osime OC and Elusojin SO. Analysis of gunshot injuries in a semi-urban community in Nigeria. Annals of Biomedical Sciences. 2009; 8 (1):133-139.

[16] Akhiwu WO and Igbe AP. Fatal gunshot injuries in Benin City, Nigeria. Medicine, Science and Law. 2013; 53(4): 199-202.

[17] Nnoli MA, Nwabuko CO and Nnoli C. Autopsy Review of Gunshot Deaths in A South Eastern Tertiary Hospital of Nigeria from 2008-2012. Journal of Dental and Medical Sciences. 2013; 5(3):63-65.

[18] Nzewuihe CAE, Onumaegbu 00 and Onah II. Pattern of gunshot injuries as seen at National Orthopedic Hospital Enugu: January 1999-December 2004. Nigerian Journal of Medicine. 2007; 16(3):235-8.

[19] Chalya PL and Gilyoma JM. The burden of intentional injuries in Mwanza City, North-western Tanzania: A tertiary hospital survey. Tanzania Journal of Health Research. 2012; 14(3):204-11.

[20] Feliciano DV, Burch JM, Spjut-Patrinely V, Mattox KL and Jordan GL. Abdominal Gunshot Wounds: An Urban Trauma Center's Experience with 300 Consecutive Patients. Annals of Surgery.1988; 208(3):362-7.

[21] Iloh GP, Chuku A, Ofoedu JN, Ugwele OH, Onyekwere JO and Amadi AN. The emerging trend in the epidemiology of gunshot injuries in the emergency department of a Nigerian tertiary hospital in a State without formal prehospital emergency medical services. Annals of Tropical Medicine and Public Health. 2013: 6:435-40.

[22] Aşirdizer M, Cantürk G, Cantürk N, Yavuz MS and Sari H. Analyses of suicidal deaths with shotguns in Istanbul, 1998-2007. Turkish journal of Trauma and Eemergency Surgery. 2010; 16(1):47-53.

[23] Ojo E, Ibrahim A, Alabi S and Obiano S. Gunshot Injuries In A North Eastern Nigerian Tertiary Hospital. Internet Journal of Surgery. 2007; 16(2):1-8.

[24] Zavoski RW, Lapidus GD, Lerer TJ and Banco LI. A population-based study of severe firearm injury among children and youth. Paediatrics. 1995; 96(2 Pt 1):278-82.

[25] Penn-Barwell, Brown KV and Fries CA. High-velocity guNshot wounds to the extremities: management on and off the battlefield. Current Reviews in Musculoskeletal Medicine. 2015; 8(3):312-7. 
[26] Azam Khan Khetran, Samina Rehman, Zahirkhan and Mujeeb-ur-Rehman Baloch. Incidence of death due to gunshot injuries at district Barkhan, Balochistan. Journal of Liaquat University of Medicine and Health Sciences. 2012; 11(2):90-92.

[27] Udosen AM, Etiuma AU, Ugare UG and Bassey 00. Gunshot injuries in Calabar, Nigeria: an indication of increasing societal violence and police brutality. African Health Sciences. 2006; 6(3):170-2.

[28] Babita D Bhana. Custody-Related Deaths in Durban, South Africa. 1998-2000. American Journal of Forensic Medicine and Pathology. 2003; 24:202 - 7.

[29] Strajina V, Živković V and Nikolić S. Forensic issues in suicidal single gunshot injuries to the chest: an autopsy study. American Journal of Forensic Medicine and Pathology. 2012; 33(4):373-6.

[30] Druid H. Site of entrance wound and direction of bullet path in firearm fatalities as indicators of homicide versus suicide. Forensic Science International. 1997; 88(2):147-62.

[31] Solarino B, Nicoletti EM and Di Vella G. Fatal firearm wounds: a retrospective study in Bari (Italy) between 1988 and 2003. Forensic Scence International. 2007; 24, 168(2-3):95-101.

[32] Aliyu S, Ibrahim AG, Mohammed BS and Jatau J. Gunshot injuries in Maiduguri North-Eastern Nigeria. International Journal of Applied Research. 2016; 2(3):539-541.

\section{How to cite this article}

Nnadi IG and Egejuru RO. (2020). Gunshot injuries in Owerri, a 10 years (2001-2010) postmortem study. World Journal of Advanced Research and Reviews, 7(2), 99-104. 